\title{
ADVOKASI GIZI PADA KADER POSYANDU DI DESA ORO-ORO OMBO KEC MATAN BATU KOTA BATU
}

\author{
Oleh: \\ Santoso Budiarjo, Rudy Joegijantoro, dan M N Lisan Sediawan \\ STIKES Widyagama Husada
}

\begin{abstract}
Malnutrition in children under 5 years old in Indonesia is a common problem in our society, especially in rural areas. This is evidenced by the high prevalence of malnutrition among children under five are related to the high infant born with low weight. Coverage of exclusive breastfeeding 0-6 months in Kecamatan Batu only reached $26.1 \%$ were categorized as low when compared to the target of $67 \%$. This is caused by a lack of public awareness about the importance of exclusive breastfeeding for $69.2 \%$ and lack of socialization to the community KADARZI of $92.3 \%$ and the need for cooperation between Puskesmas, cadres , PKK and crosssector and citizens are well established in order to achieve the target program. In order to help overcome these problems it is necessary to be implemented at the village level cadres empowerment. Programmed activities include Survelians, Advocacy, Training and Extension .
\end{abstract} Keywords : Advocacy, Surveillance, Malnutrition AND Training. 


\begin{abstract}
ABSTRAK
Masalah kurang gizi pada balita di Indonesia adalah permasalahan yang umum terjadi di masyarakat, khususnya di pedesaan. Hal ini dibuktikan dengan tingginya prevalensi gizi kurang pada anak balita yang berhubungan dengan masih tingginya bayi lahir dengan berat badan rendah. Cakupan pemberian ASI Eksklusif $0-6$ bulan di Kecamatan Batu hanya mencapai 26,1\% yang dikategorikan rendah bila dibandingkan dengan target yaitu 67\%. Hal ini disebabkan karena kurangnya kesadaran masyarakat tentang pentingnya ASI Ekslusif sebesar 69,2 \% dan kurangnya sosialisasi KADARZI kepada masyarakat sebesar 92,3\% serta perlu adanya kerjasama antara petugas puskesmas, kader, PKK dan lintas sektor serta warga yang terjalin dengan baik agar dapat mencapai target program. Dalam rangka membantu mengatasi permasalahan tersebut maka perlu dilaksanakan pemberdayaan Kader di tingkat desa. Kegiatan yang diprogramkan meliputi Survelians, Advokasi, Pelatihan dan Penyuluhan.
\end{abstract}

Kata Kunci: Advokasi , Surveilans, kekurangan Gizi dan Pelatihan Kader

\section{PENDAHULUAN}

\section{Latar Belakang Masalah}

Upaya perbaikan gizi masyarakat sebagaimana disebutkan di dalam undang-undang No 36 tahun 2009 bertujuan untuk meningkatkan mutu gizi perseorangan dan masyarakat, antara lain melalui perbaikan pola konsumsi makanan, perbaikan perilaku sadar gizi dan peningkatan akses dan mutu pelayanan gizi dan kesehatan sesuai dengan kemajuan ilmu dan teknologi. Di samping itu didalam Sistem Kesehatan Nasional telah tercantum tujuan dari pembangunan kesehatan yaitu suatu upaya penyelenggaraan kesehatan yang dilaksanakan oleh bangsa Indonesia guna mendapatkan kemampuan hidup sehat bagi setiap masyarakat agar dapat mewujudkan derajat kesehatan yang optimal. Untuk dapat mengukur derajat kesehatan masyarakat tersebut, digunakan beberapa indikator salah satunya adalah angka kesakitan dan kematian balita (Arisman, dkk, 2004)
Masa balita cenderung dengan masalah gizi kurang. Hal ini dibuktikan dengan tingginya prevalensi gizi kurang pada anak balita yang berhubungan dengan masih tingginya bayi lahir dengan berat badan rendah. Pevalensi BBLR ini masih berkisar antara $2 \%$ sampai $17 \%$ pada periode 1990-2000. Akibat dari BBLR dan gizi kurang pada balita akan berkelanjutan pada masalah pertumbuhan anak usia masuk sekolah. Berdasarkan hasil pemantauan Tinggi badan anak baru masuk sekolah (TBABS), diketahui bahwa prevalensi anak pendek tahun 1994 adalah 39,8\%. Prevalensi ini turun menjadi 36,1\% pada tahun 1999. Masalah gizi kurang pada balita ini dimulai dari wanita usia subur dengan masalah anemia dan gizi mikro lainnya, seperti kurang iodium, selenium, kalsium, seng yang akan mengakibatkan anak dengan risiko BBLR. Sekitar 30 juta wanita usia subur menderita Kurang Energi Kronis (KEK), yang bila hamil dapat meningkatkan risiko melahirkan 
BBLR. Setiap tahun, diperkirakan sekitar 350 ribu bayi BBLR ( $\leq 2500$ gram), sebagai salah satu penyebab utama tingginya angka gizi kurang dan kematian balita (Direktorat Jenderal Bina Kesehatan Masyarakat, 2010)

Wanita Usia Subur (WUS) dalam kondisi hamil merupakan masa yang paling rentan terhadap anemia gizi khususnya karena kekurangan zat besi. Hal ini disebabkan karena kurangnya zat besi dalam makanan, kurangnya zat gizi yang dapat membantu penyerapan zat besi dalam ubuh (protein, vitamin $C$, vitamin $\mathrm{B}$, mineral iodium ), aktifitas sebagaian besar ibu hamil cukup berat dan secara alamiah sebelum melahirkan wanita setiap bulan mengalami haid serta faktorfaktor lain yang melatarbelakanginya. Berdasarkan hal tersebut dikembangkanlah suatu program penanggulangan anemia gizi bagi ibu hamil yaitu pemberian tablet Fe 90 tablet yang bertujuan menurunkan prevalensi anemia gizi yang dapat menimbulkan resiko bayi lahir dengan berat badan rendah (Arisman, dkk, 2004).

Dari hasil kegiatan surveilans gizi yang dilakukan mulai tanggal 26 Maret sampai dengan 07 April 2012 oleh petugas Gizi dalam rangka Kadarzi, melalui pengkajian data dari laporan pencapaian hasil kegiatan program gizi Puskesmas Batu tahun 2011 didapatkan hasil yaitu ada beberapa program pencapaian puskesmas yang belum mencapai target, salah satunya adalah Pemberian tablet besi 90 tablet pada ibu hamil. Maka dari itu perlu adanya rencana intervensi gizi yaitu pentingnya KADARZI (Keluarga Sadar Gizi) dalam bentuk Pendidikan dan Pelatihan Kader dimana pengaktifan meja
4 atau penyuluhan tentang pentingnya tablet Fe pada saat hamil, makanan yang dapat mendukung penyerapan $\mathrm{Fe}$ dan cara konsumsi Fe agar tidak merasa mual muntah diseluruh posyandu masuk didalamnya Pendidikan dan Pelatihan Kader tersebut.

\section{PRIORITAS MASALAH}

Berdasarkan hasil surveilans pasif dan aktif yang dilakukan pada tanggal 26 Maret sampai dengan 7 April 2012 oleh petugas Gizi Puskesmas Batu, diperoleh hasil bahwa ada 3 (tiga) program gizi yang pencapaiannya belum mencapai target yang ditetapkan, diantaranya adalah :

1) Pemberian tablet besi 90 tablet pada ibu hamil (Fe 3) hanya mencapai 59,5\% yang dikategorikan rendah bila dibandingkan dengan target yaitu $86 \%$. Semua Desa belum mencapai target yang ditetapkan yaitu Desa Oro-oro Ombo (72,5\%), Desa Ngaglik (50,5\%), Desa Pesanggrahan (46,5\%), Desa Songgokerto $(56,2 \%)$ dan Desa Sumberejo (85,2\%).

2) MP-ASI pada anak usia $6-24$ bulan (Gakin) mencapai 97,3 \% yang dikategorikan cukup bila dibandingkan dengan target yaitu 100 \%. Ada beberapa desa yang belum mencapai target yang ditetapkan yaitu Desa Pesanggrahan $(79,4 \%)$ dan Desa Songgokerto $(45,7 \%)$.

3) Cakupan pemberian ASI Eksklusif 0 6 bulan hanya mencapai 26,1\% yang dikategorikan rendah bila dibandingkan dengan target yaitu $67 \%$. Semua Desa belum mencapai target yang ditetapkan yaitu Desa Oro-oro Ombo (7,7\%), Desa Ngaglik (18,3\%), 
Desa Pesanggrahan (15,2\%), Desa

Songgokerto (55\%) dan Desa

Sumberejo $(52,5 \%)$

Dalam memprioritaskan masalah yang akan segera ditangani, mempertimbangkan hal-hal sebagai berikut

a. Pentingnya masalah

b. Kelayakan teknologi

c. Sumber daya yang tersedia

Tabel 1. Masalah yang menjadi Prioritas Masalah

\begin{tabular}{|c|c|c|c|c|c|}
\hline \multicolumn{1}{|c|}{ Masalah } & I & T & R & $\Sigma$ & Prioritas \\
\hline $\begin{array}{l}\text { Pemberian } \\
\text { tablet besi 90 } \\
\text { tablet pada ibu } \\
\text { hamil (Fe 3) }\end{array}$ & 5 & 1 & 2 & 10 & I \\
\hline $\begin{array}{l}\text { MP-ASI pada } \\
\text { anak usia 6-24 } \\
\text { bulan (Gakin) }\end{array}$ & 1 & 1 & 2 & 2 & II \\
\hline $\begin{array}{l}\text { Cakupan } \\
\text { pemberian ASI } \\
\text { Eksklusif 0 - 6 } \\
\text { bulan }\end{array}$ & 5 & 1 & 2 & 10 & I \\
\hline
\end{tabular}

Berdasarkan tabel 1 menunjukkan bahwa prioritas masalah yang paling utama harus segera ditangani adalah Cakupan pemberian ASI Eksklusif $0-6$ bulan. Maka dari itu, perlu diketahui penyebab belum terpenuhinya angka pencapaian program tersebut dari target Puskesmas Batu tahun 2011 dengan menggunakan Metode FGD (Focus Grup Discussion) yang dilakukan kepada Kepala Puskesmas Batu, Ahli Gizi Puskesmas Batu, Bidan koordinator Puskesmas Batu, dan Bidan Desa Oro-oro Ombo. Dari hasil FGD (Focus Grup Discussion) tersebut dapat diketahui beberapa penyebab dari Cakupan pemberian ASI Eksklusif 0 - 6 bulan yang hanya mencapai 26,1\%, dikategorikan rendah bila dibandingkan dengan target yaitu 67\%. Semua Desa belum mencapai target yang ditetapkan yaitu Desa Oro-oro Ombo (7,7\%), Desa Ngaglik (18,3\%), Desa Pesanggrahan $(15,2 \%)$, Desa Songgokerto (55\%) dan Desa Sumberejo (52,5\%). Dari Wilayah kerja Puskesmas Batu Cakupan ASI Eksklusif terendah terdapat di Desa Orooro Ombo. Hal ini disebabkan karena kesibukan Ibu bekerja, pengetahuan dan kesadaran ibu bayi yang kurang tentang pentingnya ASI Eksklusif karena kurangnya pengaruh dukungan keluarga serta penyeragaman persepsi terhadap pengelompokkan umur terutama dalam pembanding perhitungan cakupan pemberian ASI Eksklusif belum ada (data Supas tahun 2011).

Dari hasil observasi ke Desa Oro-oro Ombo disimpulkan bahwa masih perlu sosialisasi melalui penyuluhan perilaku KADARZI (Keluarga Mandiri Sadar Gizi) dalam rangka Keberhasilan Program Gizi terutama pembinaan tentang pentingnya ASI Eksklusif dalam bentuk Penyuluhan kepada Kader PKK, Dasawisma, Ibu Hamil dan Keluarga, serta remaja pra nikah dan rumah tangga, tersedianya sarana menyusui di tempat-tempat umum (pojok laktasi), perlu juga dibentuknya konselor ASI di tingkat desa/kelurahan/kecamatan yang memberikan pendampingan bagi Ibu Menyusui, meningkatkan peran dasawisma untuk membentuk kelompok Ibu ASI Eksklusif dengan kegiatan pertemuan rutin 1 bulan sekali serta optimalisasi posyandu meja 4. Selain itu, perlu adanya Pendidikan dan Pelatihan Kader untuk dapat memaksimalkan dan mengkampanyekan kegiatan tersebut.

\section{Rencana Persiapan Advokasi}

Proses persiapan Advokasi dimulai dari masalah yang ditemukan melalui 
kegiatan surveilans gizi. Kegiatan surveilans gizi ini dilakukan secara pasif dan aktif di wilayah Puskesmas Batu. Surveilans Pasif dengan berbagai data yang ada diantaranya dari Laporan bulanan F2 Gizi, data Supas tahun 2011 dan target SPM Puskesmas Batu tahun 2011. Surveilans Aktif dengan mengamati kegiatan posyandu, kunjungan rumah dan wawancara ibu bayi. Adapun kegiatan yang dilakukan pada saat advokasi antara lain :

1. Pemaparan permasalahan dari hasil surveilans gizi kepada Kepala Puskesmas, Pelaksana Gizi Puskesmas, pemegang program promkes dan bidan koordinator Puskesmas serta bidan desa wilayah kerja Puskesmas Batu.

2. Hasil kesepakatan dan dukungan dengan Kepala Puskesmas, Pelaksana Gizi Puskesmas, pemegang program promkes, bidan koordinator Puskesmas, bidan desa wilayah kerja Puskesmas Batu, BAPPEDA, BPMPKB, Diknas, Desperindag, KPPT, pertanian, Ketahanan Pangan, Kesehatan (lintas program) dan PKK.

\section{TUJUAN}

\section{Umum}

Mendapat dukungan dari berbagai pihak baik tingkat puskesmas dan Dinas Kesehatan Kota Batu serta dari berbagai sektor terkait dalam rangka meningkatkan partisipasi masyarakat Kota Batu untuk mengatasi masalah kesehatan dan gizi yang ada di wilayah kerja puskesmas Batu dan Dinas Kesehatan Kota Batu dengan mengadakan berbagai kegiatan yang dapat membantu menyelesaikan permasalahan gizi tersebut.

\section{Khusus}

1. Meningkatkan cakupan Pemberian ASI Eksklusif bagi bayi usia 0 -6 bulan

2. Meningkatkan kemitraan dan pemberdayaan masyarakat dalam perilaku KADARZI (Keluarga Mandiri Sadar Gizi).

3. Mendapatkan dukungan dari berbagai pihak yang terkait dalam melaksanakan kegiatan tersebut agar tujuan bersama dapat tercapai.

\section{HASIL YANG AKAN DICAPAI}

Dengan dilakukannya advokasi tentang masalah gizi yang ada di wilayah Kerja Puskesmas Batu khususnya di 5 desa wilayah kerja Puskesmas Batu baik melalui advokasi lintas program maupun lintas sektor dengan saran program yang akan dilakukan, maka diharapkan adanya peningkatan cakupan Pemberian ASI Eksklusif pada bayi usia 0-6 bulan sesuai dengan target yang ditetapkan yaitu sebesar 67\% ( tahun 2011 ). Dengan tercapainya program pemberian ASI Ekslusif pada bayi usia 0-6 bulan maka prevalensi kematian bayi neonatal dapat diminimalisir sesuai dengan target yang ditentukan yaitu sebesar $67 \%$, tercapainya target tersebut secara tidak langsung dapat juga meningkatkan mutu kecerdasan masyarakat dalam rangka mempersiapkan SDM yang handal demi kemajuan bangsa dan negara khususnya Kota Batu melalui pemberian ASI Eksklusif pada bayi usia 0-6 bulan.

PELAKSANAAN ADVOKASI

Tinjauan Program 
Peraturan Pemerintah (PP) Republik Indonesia Nomor 33 tahun 2012 mengenai Pemberian ASI Eksklusif telah disahkan. PP ini akan mengatur mengenai hak dan kewajiban para pemangku kepentingan dalam memenuhi pemberian ASI ekslusif bagi bayi. Peraturan pemerintah ini disahkan guna menjamin pemenuhan hak bayi untuk mendapatkan sumber makanan terbaik (ASI) sejak dilahirkan sampai berusia 6 bulan. Selain itu, PP ASI itu akan menjamin perlindungan Ibu dalam memberikan ASI eksklusif kepada bayinya. Peraturan pemerintah itu membahas mengenai :

1. Program Inisiasi Menyusu Dini (IMD) dan ASI Eksklusif,

2. Pengaturan penggunaan susu formula dan produk bayi lainnya,

3. Sarana menyusui di tempat kerja dan sarana umum lainnya,

4. Dukungan Masyarakat tanggung jawab Pemerintah, Pemerintah Daerah baik Provinsi maupun Kabupaten/Kota dalam serta pendanaannya.

Peraturan Pemerintah

Republik Indonesia Nomor 33 tahun 2012 itu sangat dibutuhkan untuk memastikan agar pola pemberian makan untuk bayi hingga usia 2 tahun tidak terhambat dengan kondisi lain seperti tidak adanya ruang menyusui di kantor. Pola pemberian makan terbaik untuk bayi sampai anak berumur 2 tahun meliputi pemberian ASI kepada bayi segera dalam waktu 1 jam pasca kelahiran melalui Inisiasi Menyusu Dini (IMD), memberikan hanya ASI saja sejak lahir sampai umur 6 bulan tanpa menambah atau mengganti dengan makanan atau minuman lain, memberikan Makanan Pendamping ASI (MP-ASI) yang tepat sejak usia 6 bulan serta meneruskan pemberian ASI sampai anak berumur dua tahun. ASI telah dibuktikan dapat menurunkan risiko bayi terkena infeksi akut dan penyakit kronis di masa mendatang. Maka dari itu, setiap Ibu melahirkan dianjurkan dapat memberikan ASI secara eksklusif kepada bayinya, kecuali dalam kondisi tertentu, seperti adanya indikasi medis, ibu tidak ada atau ibu terpisah dari bayi. Dengan demikian diharapkan agar dukungan berbagai pihak mulai dari Pemerintah, Pemda Provinsi dan Kab/Kota, Penyelenggara Pelayanan Kesehatan, Tenaga Kesehatan, masyarakat serta keluarga terdekat ibu dapat diberikan untuk menyukseskan keberhasilan pemberian ASI Eksklusif.

Intervensi Cakupan pemberian ASI Eksklusif yang rendah dapat dilakukan melalui kegiatan :

1. Penyuluhan kepada Kader PKK, Dasawisma, Ibu Hamil dan Keluarga, serta remaja pra nikah dan rumah tangga

2. Tersedianya sarana menyusui di tempat-tempat umum (pojok laktasi).

3. Pembentukan konselor ASI di tingkat desa/kelurahan/kecamatan yang memberikan pendampingan bagi Ibu Menyusui

4. Peran dasawisma untuk membentuk kelompok Ibu ASI Eksklusif dengan kegiatan pertemuan rutin 1 bulan sekali

5. Optimalisasi posyandu meja 4 
6. Pendidikan dan Pelatihan Kader untuk dapat memaksimalkan dan mengkampanyekan kegiatan tersebut.

\section{PELAKSANAAN PROGRAM}

Peraturan Pemerintah (PP) Republik Indonesia Nomor 33 tahun 2012 mengenai Pemberian ASI Eksklusif telah disahkan. PP ini akan mengatur mengenai hak dan kewajiban para pemangku kepentingan dalam memenuhi pemberian ASI ekslusif bagi bayi. Peraturan pemerintah ini disahkan guna menjamin pemenuhan hak bayi untuk mendapatkan sumber makanan terbaik (ASI) sejak dilahirkan sampai berusia 6 bulan.Selain itu, PP ASI itu akan menjamin perlindungan Ibu dalam memberikan ASI eksklusif kepada bayinya. Peraturan pemerintah tersebut membahas mengenai :

1. Program Inisiasi Menyusu Dini (IMD) dan ASI Eksklusif,

2. Pengaturan penggunaan susu formula dan produk bayi lainnya,

3. Sarana menyusui di tempat kerja dan sarana umum lainnya,

4. Dukungan Masyarakat tanggung jawab Pemerintah, Pemerintah Daerah baik Provinsi maupun Kabupaten/Kota dalam serta pendanaannya.

Peraturan Pemerintah (PP) Republik Indonesia Nomor 33 tahun 2012 itu sangat dibutuhkan untuk memastikan agar pola pemberian makan untuk bayi hingga usia 2 tahun tidak terhambat dengan kondisi lain seperti tidak adanya ruang menyusui di kantor. Pola pemberian makan terbaik untuk bayi sampai anak berumur 2 tahun meliputi pemberian ASI kepada bayi segera dalam waktu 1 jam pasca kelahiran melalui Inisiasi Menyusu Dini (IMD), memberikan hanya ASI saja sejak lahir sampai umur 6 bulan tanpa menambah atau mengganti dengan makanan atau minuman lain, memberikan Makanan Pendamping ASI (MP-ASI) yang tepat sejak usia 6 bulan serta meneruskan pemberian ASI sampai anak berumur dua tahun.ASI telah dibuktikan dapat menurunkan risiko bayi terkena infeksi akut dan penyakit kronis di masa mendatang. Maka dari itu, setiap Ibu melahirkan dianjurkan dapat memberikan ASI secara eksklusif kepada bayinya, kecuali dalam kondisi tertentu, seperti adanya indikasi medis, ibu tidak ada atau ibu terpisah dari bayi. Dengan demikian diharapkan agar dukungan berbagai pihak mulai dari Pemerintah, Pemda Provinsi dan Kab/Kota, Penyelenggara Pelayanan Kesehatan, Tenaga Kesehatan, masyarakat serta keluarga terdekat ibu dapat diberikan untuk menyukseskan keberhasilan pemberian ASI Eksklusif.

Intervensi Cakupan pemberian ASI Eksklusif yang rendah dapat dilakukan melalui kegiatan :

1. Penyuluhan kepada Kader PKK, Dasawisma, Ibu Hamil dan Keluarga, serta remaja pra nikah dan rumah tangga

2. Tersedianya sarana menyusui di tempat-tempat umum (pojok laktasi).

3. Pembentukan konselor ASI di tingkat desa/kelurahan/kecamatan yang memberikan pendampingan bagi Ibu Menyusui

4. Peran dasawisma untuk membentuk kelompok Ibu ASI Eksklusif dengan 
kegiatan pertemuan rutin 1 bulan sekali

5. Optimalisasi posyandu meja 4

6. Pendidikan dan Pelatihan Kader untuk dapat memaksimalkan dan mengkampanyekan kegiatan tersebut.

\section{Survelian gizi.}

Surveilans gizi adalah kegiatan analisis secara sistematis dan terus menerus terhadap masalah gizi buruk dan indikator pembinaan gizi masyarakat agar dapat melakukan tindakan penanggulangan secara efektif, efisien dan tepat waktu melalui proses pengumpulan data, pengolahan, penyebaran informasi kepada penyelenggara program kesehatan dan tindak lanjut sebagai respon terhadap perkembangan informasi. Sehingga surveilans gizi akan meningkatkan efektivitas program dengan mempertajam upaya penanggulangan masalah gizi secara tepat waktu, tempat, sasaran dan jenis tindakannya Tujuan kegiatan ini adalah:

a. Mengetahui jenis program gizi yang telah dilakukan dan hasil evaluasi program gizi di wilayah Puskesmas Batu Kota Batu khususnya di Desa Oro-Oro Ombo.

b. Mengetahui kegiatan gizi yang belum mencapai target SPM Puskesmas Batu di wilayah Puskesmas Batu Kota Batu khususnya di Desa Oro-Oro Ombo.

c. Mengetahui faktor - faktor penyebab belum tercapainya kegiatan gizi di wilayah Puskesmas Batu Kota Batu khususnya di Desa Oro-Oro Ombo.

Mengetahui rencana intervensi dan advokasi yang akan dilakukan sesuai dengan kegiatan gizi yang belum mencapai target SPM Puskesmas Batu di wilayah Puskesmas Batu Kota Batu khususnya di Desa Oro-Oro Ombo Hasil dari kegiatan surveilans ini diperoleh hasil bahwa cakupan program gizi Puskesmas Batu di wilayah kerja Desa Oro-oro Ombo dapat diketahui dari Laporan bulanan (F2) Gizi tahun 2012. Kemudian dari laporan bulanan tersebut dilanjutkan dengan membandingkan antara sasaran tahun 2012 dengan target SPM Puskesmas Batu tahun 2012 yang disajikan dalam Lampiran 3. Berdasarkan hasil surveilans gizi diperoleh hasil bahwa ada beberapa program gizi yang pencapaiannya belum mencapai target yang ditetapkan, diantaranya adalah :

a. Angka pencapaian Pemberian tablet besi 90 tablet pada ibu hamil (Fe 3) sebesar 59,5\% (target SPM Puskesmas Batu tahun 2012 minimal $86 \%$ )

b. Angka pencapaian MP-ASI pada anak usia 6 - 24 bulan (Gakin) sebesar 97,3\% (target SPM Puskesmas Batu tahun 2012 adalah $100 \%$ )

c. Angka pencapaian cakupan pemberian ASI Eksklusif $0-6$ bulan sebesar 26,1\% (target SPM Puskesmas Batu tahun 2012 minimal $67 \%$ )

\section{Advokasi gizi}

Dari hasil kegiatan surveilans gizi yang dilakukan 2 -22 September 2013 oleh tim Ibm bersama Puskesmas Batu, melalui pengkajian data dari laporan pencapaian hasil kegiatan program gizi Puskesmas Batu tahun 2012 didapatkan hasil yaitu ada beberapa program pencapaian puskesmas yang belum mencapai target, salah satunya adalah Pemberian tablet besi 90 tablet pada ibu hamil. Maka dari itu perlu adanya rencana intervensi gizi 
yaitu pentingnya KADARZI (Keluarga Sadar Gizi) dalam bentuk Pendidikan dan Pelatihan Kader.

Berdasarkan hasil surveilans pasif dan aktif diperoleh hasil bahwa ada 3 (tiga) program gizi yang pencapaiannya belum mencapai target yang ditetapkan, diantaranya adalah :

a. Pemberian tablet besi 90 tablet pada ibu hamil (Fe 3) hanya mencapai $59,5 \%$ yang dikategorikan rendah bila dibandingkan dengan target yaitu $86 \%$.

b. MP-ASI pada anak usia $6-24$ bulan (Gakin) mencapai 97,3 \% yang dikategorikan cukup bila dibandingkan dengan target yaitu 100 $\%$.

c. Cakupan pemberian ASI Eksklusif 0 6 bulan hanya mencapai 26,1\% yang dikategorikan rendah bila dibandingkan dengan target yaitu $67 \%$.

Dalam memprioritaskan masalah yang akan segera ditangani, mempertimbangkan hal-hal sebagai berikut

a) Pentingnya masalah

b) Kelayakan teknologi

c) Sumber daya yang tersedia

Berdasarkan analisa melalui Focus Group Disscusion( FGD) aktif dan pasif menunjukkan bahwa prioritas masalah yang paling utama harus segera ditangani adalah Cakupan pemberian ASI Eksklusif $0-6$ bulan. Maka dari itu, perlu diketahui penyebab belum terpenuhinya angka pencapaian program tersebut dari target Puskesmas Batu tahun 2011 dengan menggunakan Metode FGD (Focus Grup Discussion) yang dilakukan kepada Kepala Puskesmas Batu, Ahli Gizi
Puskesmas Batu, Bidan koordinator Puskesmas Batu, dan Bidan Desa Oro-oro Ombo. Melalui kegiatan ini dapat diketahui beberapa penyebab dari Cakupan pemberian ASI Eksklusif $0-6$ bulan yang hanya mencapai $26,1 \%$, dikategorikan rendah bila dibandingkan dengan target yaitu 67\%. Dari Wilayah kerja Puskesmas Batu Cakupan ASI Eksklusif terendah terdapat di Desa Orooro Ombo. Hal ini disebabkan karena kesibukan Ibu bekerja, pengetahuan dan kesadaran ibu bayi yang kurang tentang pentingnya ASI Eksklusif karena kurangnya pengaruh dukungan keluarga serta penyeragaman persepsi terhadap pengelompokkan umur terutama dalam pembanding perhitungan cakupan pemberian ASI Eksklusif belum ada.

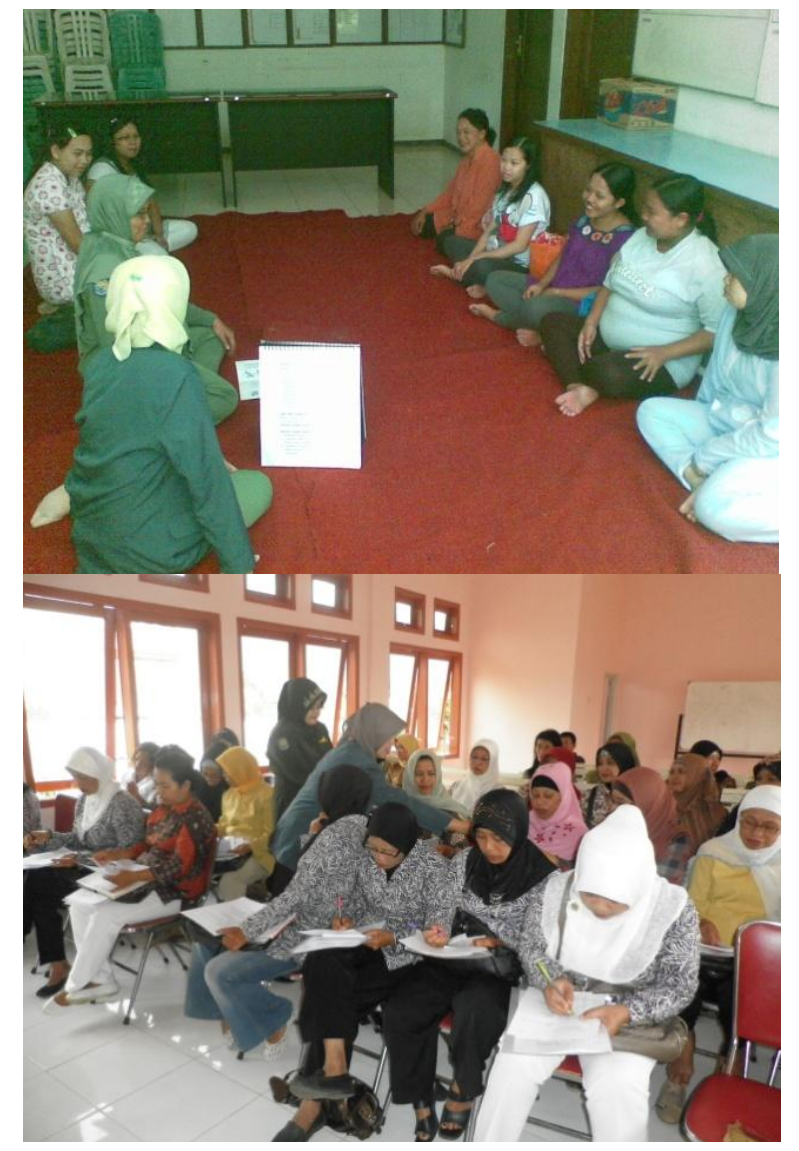

Gambar : Dokumentasi Kegiatan

Advokasi 
Dari hasil observasi ke Desa Oro-oro Ombo disimpulkan bahwa masih perlu sosialisasi melalui penyuluhan perilaku KADARZI (Keluarga Mandiri Sadar Gizi) dalam rangka Keberhasilan Program Gizi terutama pembinaan tentang pentingnya ASI Eksklusif dalam bentuk Penyuluhan kepada Kader PKK, Dasawisma, Ibu Hamil dan Keluarga, serta remaja pra nikah dan rumah tangga, tersedianya sarana menyusui di tempat-tempat umum (pojok laktasi), perlu juga dibentuknya konselor ASI di tingkat desa/kelurahan/kecamatan yang memberikan pendampingan bagi Ibu Menyusui, meningkatkan peran dasawisma untuk membentuk kelompok Ibu ASI Eksklusif dengan kegiatan pertemuan rutin 1 bulan sekali serta optimalisasi posyandu meja 4. Selain itu, perlu adanya Pendidikan dan Pelatihan Kader untuk dapat memaksimalkan dan mengkampanyekan kegiatan tersebut.

\section{Pelatihan Kader}

Di tengah-tengah maraknya dunia informasi dan media Panggung boneka masih menjadi hiburan anternatif bagi anak-anak untuk menyampaikan pesan, baik pesan karakter, nilai agama ataupun pelajaran di sekolah sampai permasalahan kesehatan. Panggung boneka harus di bangkitkan dan digalakan khususnya di sekolah-sekolah atau pendidikan Usia dini, karena pertunjukan ini sangat efektif untuk menyampaikan pesan-pesan yang di kemas lewat hiburan. Bermain dalam panggung boneka atau menjadi dalang tidaklah semudah yang Anda pikirkan. Dibutuhkan latihan menyeluruh dan konsisten sebelum Anda dapat menjadi ahli. Pemain perlu mempelajari teknik yang berbeda seperti posisi dasar, diksi, batang lengan dan gerakan tubuh. Jenis yang paling umum dari boneka tangan adalah boneka tangan sederhana dan boneka tangan yang lebih besar.

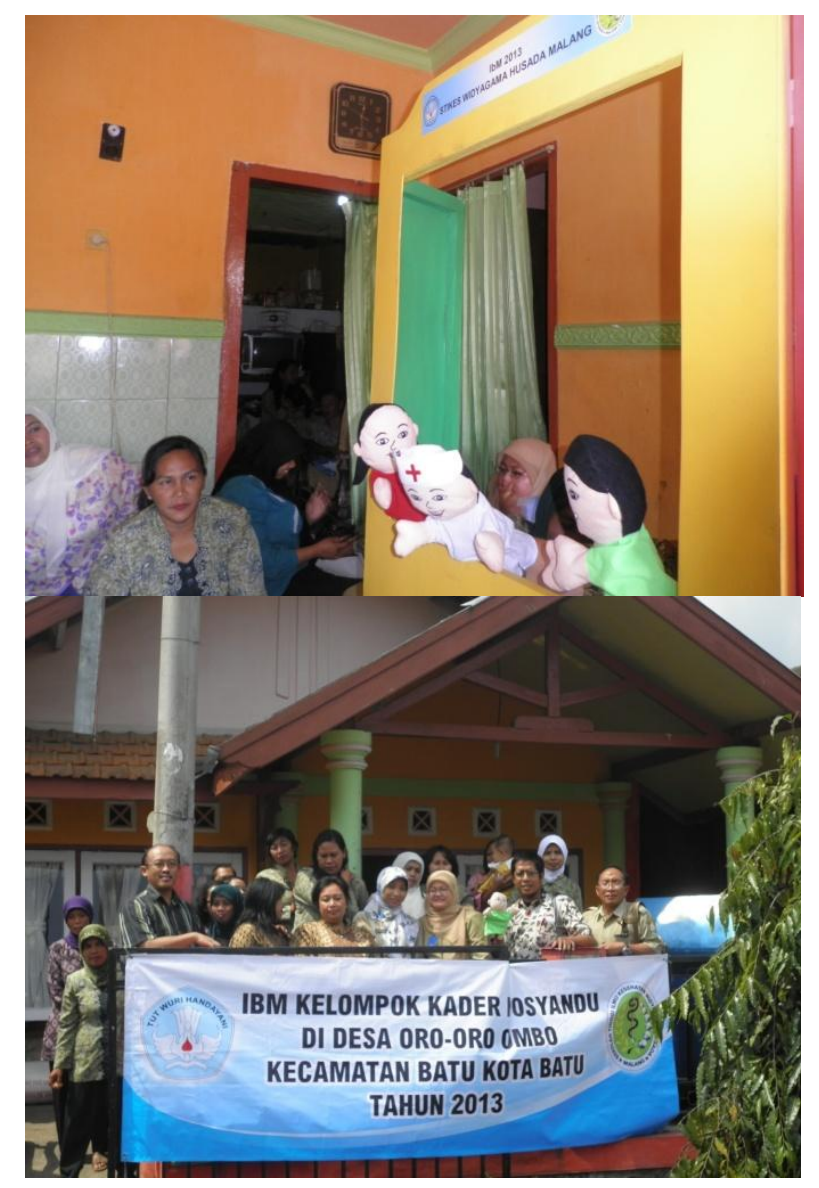

\section{Gambar : Dokumentasi Kegiatan pelatihan Kader}

Setiap boneka memiliki penggunaan yang berbeda dalam pertunjukan boneka. Boneka tangan sederhana memiliki beberapa bagian yang bergerak atau tidak ada sama sekali. Mereka biasanya terdiri dari bahan fleksibel dan memiliki fitur wajah yang berbeda seperti mata dan hidung. Mulut sering disertakan pada boneka tangan sederhana tetapi biasanya ada hanya untuk keperluan desain. Ia bahkan tidak membuka atau menutup kecuali ibu jari memasuki saku yang memungkinkan untuk bergerak 
Media Panggung boneka adalah salah satu media yang akan digunakan oleh kader gizi dalam rangka memberikan advokasi atau penyuluhan gizi (ASI eksklusif) bagi ibu menyusui. Untuk membekali para kader gizi dalam menyampaikan materi penyuluhan melalui panggung boneka maka perlu dilaksanakan terlebih dahulu pelatihan panggung boneka yang dilaksanakan di salah satu rumah kader desa Oro-Oro Ombo tanggal 18 dan 23 Oktober 2013.

\section{KESIMPULAN DAN SARAN}

1. Perlu adanya Rencana Tindak Lanjut dari Kegiatan Surveilans Gizi untuk meningkatkan efektivitas program dengan mempertajam upaya penanggulangan sesuai dengan masalah yang ada secara tepat waktu, tempat, sasaran dan jenis tindakan yang akan dilakukan.

2. Perlu adanya pemantapan kegiatan advokasi yang melibatkan partisipasi lintas sektoral baik dari dinas kesehatan maupun dari dinas-dinas terkait.

3. Kerjasama dengan Perguruan Tinggi sangat dibutuhkan demi peningkatan kualitas kesehatan masyarakat desa, khususnya pada kegiatan Gizi dan ASI ekslusif.

4. Perlu direncanakan kegiatan yang periodik terutama dalam memberdayakan peran kader kesehatan di desa-desa dalam rangka meningkatkan derajat kesehatan masyarakat.

\section{DAFTAR PUSTAKA}

Arisman dan Palupi Widyastuti. 2004. Gizi dalam Daur Kehidupan. Jakarta: EGC

Direktorat Jenderal Bina Kesehatan Masyarakat. 1994. Buku Kader UPGK. Jakarta: Kementerian Kesehatan RI.

Direktorat Jenderal Bina Kesehatan Masyarakat. 2010. Surveilans Gizi di Tingkat Kabupaten / Kota. Jakarta: Kementerian Kesehatan RI.

Direktorat Jenderal Bina Gizi Kesehatan Ibu dan Anak. 2011. Petunjuk Pelaksanaan Surveilans Gizi Khusus di Kabupaten / Kota. Jakarta: Kementerian Kesehatan RI.

Kementerian Kesehatan RI. 2010. Pedoman Pelaksanaan Surveilans Gizi di Kabupaten/Kota. Jakarta: Direktorat Jenderal Bina Kesehatan Masyarakat.

Pusat Komunikasi Publik Kementerian Kesehatan. 2012. PPRI No. 33 tahun 2012 tentang Pemberian ASI Eksklusif. Jakarta: Kementerian Kesehatan RI. 